\title{
Chemical and Sensory Evaluation of African Yam Bean (Sphenostylis Sternocarpa) Seed-Enriched Cassava (Manihot esculenta) Product (Pupuru)
}

\author{
Folayemi J. Isaac-Bamgboye*, Victor N. Enujiugha, and Matthew O. Oluwamukomi. \\ Department of Food Science and Technology, Federal University of Technology, P. M. B. 747, Akure, \\ Nigeria. \\ *E-mail: yemistyle@gmail.com
}

\begin{abstract}
This study evaluated the proximate composition, total energy values and mineral profiles of Pupuru flour blends produced from fermented cassava (Manihot esculenta Crantz) roots enriched with African yam bean (Sphenostylis stenocarpa) seeds (AYBS) and sensory qualities of stiff dough meals prepared from them. African yam bean seeds were cleaned, washed with and soaked in clean water for $24 \mathrm{~h}$, manually dehulled, rinsed, cooked for about 45 min, rinsed, dried in an oven at $60^{\circ} \mathrm{C}$ for $5 \mathrm{~h}$, cooled to about $30 \pm 2{ }^{\circ} \mathrm{C}$, milled, sieved and added to cassava which was previously spontaneously-fermented for $96 \mathrm{~h}$, toasted, cooled, milled, sieved and packaged to form Pupuru flour blends of various proportions (0:100 (P100), 5:95 (EP5), 10:90 (EP10) 15:85 (EP15) of AYB seed : cassava) and a commercial sample (CP) was used as a control. The proximate compositions indicated significant $(\mathrm{p}<0.05)$ reductions in moisture, fibre and carbohydrate but increased the protein, fat and ash contents and energy values of all the blends as enrichment levels with AYBS increased. Moisture (dry basis), protein, fat, fibre, ash, carbohydrate and total energy contents of the blends ranged from $6.78-9.26 \%, 3.18-21.74 \%, 2.18-4.98 \%, 2.79-3.57 \%, 2.91$ $-3.93 \%, 59.78-80.26 \%$ and $364.02-387.20 \mathrm{Kcal}$, respectively. Mineral compositions were significantly $(\mathrm{P}<0.05)$ different: Sodium (143.00-187.00 mg/100g), Potassium (537.00-675.00 mg/100g), Calcium (129.30-201.50 $\mathrm{mg} / 100 \mathrm{~g})$, Phosphorus (63.50-124.00 mg/100g), Magnesium (49.10-71.00 mg/100g), Copper (2.3-3.4 mg/100g), Manganese (1.20-21.20 mg/100g), Zinc (4.50-11.00 mg/100g), Iron (5.20-12.50 mg/100g) while lead was below detection level. All samples had good sensory scores and overall acceptability. Enrichment of Pupuru with AYBS, significantly $(\mathrm{p}<0.05)$ improved proximate and energy compositions, mineral profile, and sensory properties, hence, could be used to enhance food security and combat malnutrition in Africa.
\end{abstract}

Keywords: Pupuru, Cassava, African yam bean (Sphenostylis stenocarpa) seed, Malnutrition, Food security

DOI: $10.7176 / \mathrm{FSQM} / 96-07$

Publication date: April $30^{\text {th }} 2020$

\section{Introduction}

Pupuru, is a dough meal, traditionally fermented, ball-moulded, smoke-dried cassava food, native to the Ilajes of Ikale tribe, Ondo State and popularly consumed by the riverine area dwellers in the Southern, Eastern, Western and Middle belts of Nigeria (where it is known as Ikwurikwu) (Shittu et al., 2003; Aboaba et al., 1988). It serves as a major income source for those who produce it from cassava and plays a substantial role in enhancing food security in Nigeria (Opeke et al., 1986). Cassava is predominantly carbohydrate, with a deficiency in protein (1 2\%, fresh weight (Charles et al., 2005), 1-3\% dry weight (Buitrago, 1990), minerals and vitamins, and a rapid postharvest deterioration limit its utilisation as a vital food and feed in Africa (Kimaryo et al., 2000; Nwabueze and Odunsi, 2006; Wobeto et al., 2007; Chauynarong et al., 2009; Ogunjobi and Ogunwolu, 2010). Cassava is a staple food in various forms, such as Garri, Lafun, Fufu, Abacha, Agbelima, Tapioca, Attieke and Pupuru, for about 500 million people, in the developing countries (Okafor et al., 1998). In view of the low protein content of cassava, on a dry matter basis, and the safety implication of the inadequately smoke-dried, moulded Pupuru balls, this study, therefore, utilised the underutilised African yam bean (Sphenostylis stenocarpa) (AYB) seed at 5, 10 and $15 \%$ substitutions for Pupuru fortification, toasting as opposed to smoke-drying the spontaneously fermented cassava (TMS 0581) and AYB seed paste blends and investigated the proximate and mineral compositions of the AYB seed-fortified Pupuru flours blends, using standard methods.

\section{$2 \quad$ Materials and methods}

2.1 Materials

Fresh cassava (Manihot esculenta, Crantz) (TME 0581) tubers were sourced from the research farm of the Federal 
University of Technology, Akure, Ondo State, African Yam Bean (AYB) (Sphenostylis stenocarpa) seeds (TSs 091) were from a farm in Efon Alaaye, Ekiti State and characterised by the International Institute of Tropical Agriculture (IITA), Ibadan, Oyo State while chemicals of analytical grade were purchased from a local chemical store in Akure, Ondo State.

\section{$2.2 \quad$ Methods}

Pre-processing of African yam bean (AYB) (Sphenostylis stenocarpa) seeds

African yam bean seeds (AYBS) were pre-processed into flour using modified method of Oluwamukomi and Akinlabi, 2011. The seeds were manually cleaned to remove dirts, stones, defective seeds, dead insects, and other unwanted materials. The cleaned seeds were washed with and soaked in clean tap water for $24 \mathrm{~h}$, manually dehulled, rinsed, cooked for about $45 \mathrm{~min}$, drained of water, rinsed, dried in an oven at $60^{\circ} \mathrm{C}$ for $5 \mathrm{~h}$, cooled to about $30 \pm 2^{\circ} \mathrm{C}$, milled, sieved and the resultant flour was packaged in an airtight container for further uses.

Formulation of Pupuru flour blends

One kilogram $(1 \mathrm{~kg})$ of peeled, chipped and washed cassava tubers was soaked in one litre of water in a sterile plastic container and left to ferment for $96 \mathrm{~h}$. Fibrous materials were manually removed from the dewatered, fermented cassava which was then pressed with a hydraulic jack, for further removal of water before being pulverized. Various percentages (5, 10 and 15) of the African yam bean (Sphenostylis stenocarpa) seed (AYBS) flour were homogenously mixed with the fermented cassava paste before toasting in an open and wide pan until it was dry (Oluwamukomi and Akinlabi, 2011). The resultant cassava and AYBS blends (Table 1) were cooled to about $30 \pm 2{ }^{\circ} \mathrm{C}$, milled, sieved and packaged in an airtight container for further analyses. A commercial sample of Pupuru flour (CP) with 100\% cassava and another prepared during this study (P100) were both used as commercial and laboratory controls, respectively.

\subsection{Determination of Proximate Composition of Pupuru Flour Blends}

Proximate compositions of the Pupuru flour blends were determined using the method of A.O.A.C. (2012) and the carbohydrate content was obtained by difference.

Table 1. Formulated Pupuru flour blends

\begin{tabular}{|l|l|}
\hline Sample code & $\begin{array}{l}\text { Formulation ratio } \\
\text { AYBS flour: Cassava (\%) }\end{array}$ \\
\hline P100 & $0: 100$ \\
\hline EP5 & $5: 95$ \\
\hline EP10 & $10: 90$ \\
\hline EP15 & $15: 85$ \\
\hline
\end{tabular}

AYBS = African yam bean (Sphenostylis stenocarpa) seed

\section{$2.4 \quad$ Total Energy Value Determination}

The total energy values of the flour blends were calculated using the method of AOAC (2012) and the following equation:

Total energy $(\mathrm{kcal} / 100 \mathrm{~g})=[(\%$ available carbohydrates $\times 4)+(\%$ protein $\times 4)+(\%$ fat $\times 9) \quad$ Eqn. 1 .

\subsection{Mineral Content Determination}

Determination of sodium and potassium contents of each sample was carried out using flame photometry (Pearson, 1976). Phosphorus was determined by the phosphovanado-molybdate (yellow) method (AOAC, 2012) while the other elemental concentrations were determined after wet digestion of the sample ash, with a mixture of nitric and perchloric acids (1:1 v/v), using Atomic Absorption Spectrophotometer (AAS, Buck Model 20A, Buck Scientific, East Norwalk, CT06855, USA) (AOAC, 2012). All the determinations were carried out in triplicates. The AAS is based on the principle that an excited atom of an element has the ability to absorb energy from wavelengths of light of the same frequency as the element. A blank solution is used to adjust instrument to zero absorbance or $100 \%$ transmittance, working standards introduced to adjust instrument to give agreeable readings before the plant digest (prepared sample solution) was introduced. The absorbance of the digest was then recorded.

From the readings obtained, the mineral concentration in each sample was calculated thus:

$\mathrm{R}=\frac{\text { sample reading } \times 10 \mathrm{ppm}}{\text { standard reading }}$ 


$$
\mathrm{S}(\mathrm{ppm})=\frac{\mathrm{R} \times \mathrm{v}(\text { volume of sample after making up })}{\text { weight of sample }}
$$

$\mathrm{T}(\mathrm{mg} / 100 \mathrm{~g})=\mathrm{s} / 10$

Eqn. 2.

Where, $\mathrm{T}$ is the value of mineral.

\subsubsection{Determination of sodium and potassium}

Determination of sodium

Five grams $(5 \mathrm{~g})$ of sample was ashed and $10 \mathrm{ml}$ of distilled water and $5 \mathrm{ml}$ of concentrated nitric acid were added with stirring. The mixture was transferred to a $100 \mathrm{ml}$ volumetric flask and made up to the mark with distilled water. The flame photometer was set up so that the scale read 0 with distilled water and 10 divisions when the standard dilute $\mathrm{Na}$ was sprayed. The sample solution was sprayed and the $\mathrm{Na}$ content calculated by simple proportion (Pearson, 1976).

Determination of potassium

Five gram $(5 \mathrm{~g})$ of each sample was ashed and $100 \mathrm{ml}$ of distilled water and $10 \mathrm{ml}$ of concentrated $\mathrm{HCl}$ were added. The mixture was boiled for $10 \mathrm{~min}$, cooled and diluted to a final concentration of approximately $15 \mathrm{mg} / 1 \mathrm{~K}{ }_{2} \mathrm{O}$. Using a filter to give a spectrum range of $766-770 \mathrm{~nm}$, the sensitivity of the flame photometer was set so that the full deflection (100 divisions) was equivalent to $20 \mathrm{mg} / 1 \mathrm{~K}_{2} \mathrm{O}$. The diluted sample solution was sprayed and the amount of $\mathrm{K}$ in the sample was estimated from the calibration graph $\left(\mathrm{K}=0.83 \times \mathrm{K}_{2} \mathrm{O}\right)$.

\subsubsection{Determination of phosphorus}

Phosphorus was determined colorimetrically using phosphor-vanadomolybdate (yellow) method and the absorbance measured at $470 \mathrm{~nm}$ (AOAC, 2012). About $1 \mathrm{ml}$ of the sample solution was pipetted into $50 \mathrm{ml}$ volumetric flask and $10 \mathrm{ml}$ of vanadomolybdate reagent was added with few $\mathrm{ml}$ of distilled water, mixed and diluted to the volume with distilled water and allowed to stand for $10 \mathrm{~min}$. A blank solution was also prepared by mixing $5 \mathrm{ml}$ of water with $10 \mathrm{ml}$ of vanadomolybdate and making it up to $50 \mathrm{ml}$.

The standard stock solution (100 ppm phosphorus) was prepared by dissolving $4.39 \mathrm{~g}$ of anhydrous $\mathrm{KH}_{2} \mathrm{PO}_{4}$ in 1 litre of distilled water. The stock solution was further diluted down to $50 \mathrm{ppm}$. About $20 \mathrm{~g}$ of ammonium molybdate was dissolved in $200 \mathrm{ml}$ of hot distilled water and cooled. About $1 \mathrm{~g}$ of ammonium metavanadate $\left(\mathrm{NH}_{4} \mathrm{VO}_{3}\right)$ was also dissolved separately in $120 \mathrm{ml}$ of hot distilled water and cooled. Approximately, $140 \mathrm{ml}$ concentrated nitric acid $\left(\mathrm{HNO}_{3}\right)$ was gradually added to the vanadate solution and diluted to $1 \mathrm{~L}$. The absorbance of standard was read and a graph of absorbance against concentration was plotted (wavelength $470 \mathrm{~nm}$ ). Phosphorus was determined from the calibration curve obtained by taking $0,2,4,6,8$ and $10 \mathrm{ml}$ out of the $50 \mathrm{ppm}$ stock solution of phosphorus diluted to $50 \mathrm{ml}$ in a volumetric flask. The absorbance was also taken and the concentration of phosphorus was calculated thus:

$$
\begin{aligned}
& \mathrm{P}\left(\frac{\mathrm{mg}}{\mathrm{kg}}\right)=\frac{\mathrm{A} \times \mathrm{Fv} \times \mathrm{D}}{\text { Weight of sample }} \\
& \text { Where, } \\
& \quad \mathrm{A}=\text { Absorbance } \\
& \mathrm{Fv}=\text { Final volume of extract; } \\
& \mathrm{D}=\text { Dilution factor. }
\end{aligned}
$$$$
\text { Eqn. } 3
$$

\subsection{Sensory Evaluation}

Sensory characteristics (colour, taste, mouthfeel, mouldability, texture, aroma, flavor and overall acceptability) of the samples were assessed by 30 semi-trained panelists (students and staff) of Federal University of Technology, Akure, Ondo State. The panelists were in good health and familiar with the taste, flavour and other attributes of pupuru while the samples were assessed using a 9 points hedonic scale ranging between 1 (extremely like) to 9 (extremely dislike) (IFT, 1981; Larmond, (1982).

\subsection{Statistical Analysis}

All the data obtained in this study were subjected to Analysis of Variance (ANOVA) using IBM SPSS version 21. Duncan Multiple Range Tests (DMRT) were carried out for the separation of means and determination of significant differences between means. Results are presented as mean \pm standard deviation accepted at $p \leq 0.05$ 
confidence limit (Steel et al., 1997).

\section{$3 \quad$ Results and Discussions}

\subsection{Proximate Composition and Total Energy Values}

The results of the proximate analysis of the Pupuru flour blends (dry basis) are presented in Table 2. The moisture content $(\mathrm{MC})$ of all the flour blends were significantly different $(\mathrm{p}<0.05)$, ranging from 6.78 (EP15) to $7.87 \%$ $(\mathrm{P} 100)$ and were significantly $(\mathrm{p}<0.05)$ lower than in CP $(9.26 \%)$. These results implied that the samples in this study would possess longer shelf lives compared to the commercial control sample (CP). A reduction in MC with increased enrichment with AYB seed which was not significant $(\mathrm{p}<0.05)$ until at $15 \%$ inclusion of AYBS was observed. This might be due to the binding action of the protein in AYBS with water molecules. The MCs of the all the Pupuru flour blends were within the acceptable limit recommended for flour (10\%) by the FAO (2003). The protein content (PC) of all the Pupuru flour blends were significantly different $(\mathrm{p}<0.05)$, ranging from 3.48 (P100) to $21.74 \%$ (EP15), and were significantly $(\mathrm{p}<0.05)$ higher than the commercial sample $(3.18 \%)$. These results were higher than $1-3 \%$ reported by Olugbemi et al. (2010) for cassava and implied that the protein contents of all the AYB seed-enriched samples could provide half of $56 \mathrm{~g} / \mathrm{kg}$ body weight protein requirements of an adult (FAO, 2003). The fat contents (FC) ranged between 2.49 (P100) and 4.98\% (EP15) and differed significantly ( $\mathrm{p}<$ 0.05). The fat contents of the samples increased with increased inclusion of AYB seed. Thus, the increase in fat contents of the blends might have been due to the lipid content of the AYB seed. The crude fibre contents (CFC) of all the Pupuru flour blends ranged from $2.79 \%$ in EP15 to $3.08 \%$ in P100. This study showed that the CFC of the enriched flour blends were significantly $(\mathrm{p}<0.05)$ lower than the commercial control sample. The trend in the results showed reduction in crude fibre with increased percentage of AYBS substitution in the samples. The CFC reported in this study were similar to those reported by Adejuyitan (2011) and Famakin et al. (2016) for the plantain-based dough meal enriched with Soy-cake and rice bran, respectively. The variation in the results might be as a result of different crops used for the food products. The results of ash content (AC) of all the samples were significantly different $(\mathrm{p}<0.05)$ with EP15 having the highest $(3.93 \%)$ and P100 having the lowest $(2.91 \%)$ values. The AC of a food sample is the inorganic residue after the water and organic matter have been removed by heating in the presence of oxidizing agents, and is a measure of the total amount of minerals in it. The ACs of the flour blends in this study increased with increased enrichment with AYBS and implying increased mineral content. The carbohydrate content $(\mathrm{CC})$ showed significant differences $(\mathrm{p}<0.05)$, ranged from $59.78-80.26 \%$ in EP15 and P100, respectively. Significant $(\mathrm{p}<0.05)$ reductions were observed in all the Pupuru flour blends with increased inclusion of AYB seed flour and the results agreed with the findings of Montagnac et al. (2009) and AdebayoOyetoro et al. (2017) in studies on cassava flours.

Table 2. Proximate composition and total energy values of Pupuru flour blends and the commercial control sample

\begin{tabular}{|l|l|l|l|l|l|l|l|}
\hline Sample & $\begin{array}{l}\text { Moisture } \\
\text { Content }\end{array}$ & $\begin{array}{l}\text { Crude } \\
\text { Protein }\end{array}$ & $\begin{array}{l}\text { Crude } \\
\text { Fat }\end{array}$ & $\begin{array}{l}\text { Crude } \\
\text { Fibre }\end{array}$ & Ash & $\begin{array}{l}\text { Carbohydrat } \\
\text { e }\end{array}$ & $\begin{array}{l}\text { Energy } \\
(\text { Kcal })\end{array}$ \\
\hline CP & $9.26 \pm 0.02^{\mathrm{a}}$ & $3.18 \pm 0.02^{\mathrm{e}}$ & $2.18 \pm 0.02^{\mathrm{c}}$ & $3.57 \pm 0.02^{\mathrm{a}}$ & $\begin{array}{l}2.95 \pm 0.02 \\
\mathrm{~d}\end{array}$ & $78.82 \pm 0.73^{\mathrm{b}}$ & $364.02 \pm 0.13^{\mathrm{e}}$ \\
\hline P100 & $\begin{array}{l}7.87 \pm 0.02 \\
\mathrm{~b}\end{array}$ & $3.48 \pm 0.31^{\mathrm{d}}$ & $2.49 \pm 0.13^{\mathrm{c}}$ & $\begin{array}{l}3.08 \pm 0.09 \\
\mathrm{~b}\end{array}$ & $2.91 \pm 0.03^{\mathrm{e}}$ & $80.26 \pm 0.42^{\mathrm{a}}$ & $\begin{array}{l}374.12 \pm 0.30 \\
\mathrm{~d}\end{array}$ \\
\hline EP5 & $\begin{array}{l}7.47 \pm 0.17 \\
\mathrm{~b}\end{array}$ & $13.58 \pm 1.11^{\mathrm{c}}$ & $2.89 \pm 1.89^{\mathrm{c}}$ & $2.89 \pm 0.09^{\mathrm{c}}$ & $2.98 \pm 0.05^{\mathrm{c}}$ & $70.29 \pm 0.26^{\mathrm{c}}$ & $378.26 \pm 0.26^{\mathrm{c}}$ \\
\hline EP10 & $\begin{array}{l}7.45 \pm 0.01 \\
\mathrm{~b}\end{array}$ & $\begin{array}{l}18.00 \pm 0.99 \\
\mathrm{~b}\end{array}$ & $\begin{array}{l}4.19 \pm 0.64 \\
\mathrm{~b}\end{array}$ & $2.85 \pm 0.11^{\mathrm{d}}$ & $\begin{array}{l}3.23 \pm 0.53 \\
\mathrm{~b}\end{array}$ & $64.28 \pm 0.27^{\mathrm{d}}$ & $\begin{array}{l}383.27 \pm 0.21 \\
\mathrm{~b}\end{array}$ \\
\hline EP15 & $6.78 \pm 0.09^{\mathrm{c}}$ & $21.74 \pm 0.59^{\mathrm{a}}$ & $4.98 \pm 0.48^{\mathrm{a}}$ & $2.79 \pm 0.01^{\mathrm{e}}$ & $3.93 \pm 0.01^{\mathrm{a}}$ & $59.78 \pm 0.78^{\mathrm{e}}$ & $387.20 \pm 0.03^{\mathrm{a}}$ \\
\hline
\end{tabular}

Mean \pm SD with different superscripts in the same column are significantly different $(\mathrm{p}<0.05), \mathrm{n}=3$.

Key: CP = Commercial Pupuru Sample; P100 = 100\% Pupuru; EP5 = 5\% AYB-enriched Pupuru; EP10 = 10\% AYB-enriched Pupuru; EP15 = 15\% AYB-enriched Pupuru.

\subsection{Total energy values}

The energy values $(E V s)$ of the flour blends ranged with significant difference $(\mathrm{p}<0.05)$ from $374.12 \mathrm{kcal} / 100 \mathrm{~g}$ in $\mathrm{P} 100$ to $387.20 \mathrm{kcal} / 100 \mathrm{~g}$ in EP15. The EVs increased significantly $(\mathrm{p}<0.05)$ with increased AYB seed enrichment of the Pupuru flour blends, were significantly $(\mathrm{p}<0.05)$ higher than in commercial control sample $(\mathrm{CP})(364.02$ $\mathrm{Kcal} / 100 \mathrm{~g}$ ), and the recommended $344 \mathrm{Kcal} /$ day $(\mathrm{FAO}, 2004)$. The observed high energy values of these flour 
blends could be attributed to fat, protein and an appreciable quantity of carbohydrate in AYB seed. The proximate compositions of the Pupuru flour blends produced in this study indicated that they could provide the necessary nutrients and energy requirements for both children and adults, thereby, enhancing food security in Africa.

\subsection{Mineral Contents of Pupuru Flour Blends}

Tables 3 show the major mineral (Na, K, Ca, P, Mg and their ratios) compositions of commercial, spontaneouslyfermented-African yam bean (AYB) (Sphenostylis stenocarpa) seed-enriched Pupuru flour blends. The mineral compositions showed that sodium ranged between $143.00 \mathrm{mg} / 100 \mathrm{~g}$ in sample EP10 and $179 \mathrm{mg} / 100 \mathrm{~g}$ in sample EP15. These values were higher than those reported by Dossou et al. (2014) i.e. $84.24 \mathrm{mg} / 100 \mathrm{~g}, 73.37 \mathrm{mg} / 100 \mathrm{~g}$, $123.65 \mathrm{mg} / 100 \mathrm{~g}$ and $171.20 \mathrm{mg} / 100 \mathrm{~g}$ for oven dried, freeze dried, defatted oven dried and defatted freeze dried ackee apple aril respectively. The recommended daily value for sodium is $1100-3300 \mathrm{mg} / \mathrm{kg}$ for adults Bolt et al. (1978). Potassium was the most abundant mineral in the Pupuru flour blends for this study, ranging from 537.00 $\mathrm{mg} / 100 \mathrm{~g}$ in EP10 (10\% AYBS-enriched Pupuru) to $675.00 \mathrm{mg} / 100 \mathrm{~g}$ in sample EP15 (15\% AYBS-enriched Pupuru) flour blends. $\mathrm{Na} / \mathrm{K}$ ratio of less than $1 \mathrm{mg} / 100 \mathrm{~g}$ is recommended in the diet of people with high blood pressure and children with immature heart Ijarotimi and Keshinro, (2012). The $\mathrm{Na} / \mathrm{K}$ ratios of all the Pupuru flour blends were less than $1 \mathrm{mg} / 100 \mathrm{~g}$. This is an indication that the formulated flour blends would be suitable as complementary food for infants. Calcium content was between $129.30 \mathrm{mg} / 100 \mathrm{~g}$ in sample EP10 and 201.50 $\mathrm{mg} / 100 \mathrm{~g}$ in sample CP. CSEP5 had the highest calcium content $294.15 \mathrm{mg} / 100 \mathrm{~g}$. Calcium content in this study was higher when compared with smoked-dried, oven-dried, and toasted Pupuru flour which ranged from 144.1 $\mathrm{mg} / 100 \mathrm{~g}$ to $167.33 \mathrm{mg} / 100 \mathrm{~g}$ as reported by Famurewa et al. (2013). Calcium plays an important role in blood cloting, muscle contraction and in certain metabolic processes, hence, sample CSEP5 could be a good source of calcium. The calcium content was high compared to foods from other plant sources (Ijarotimi and Keshinro, 2012). The $\mathrm{Ca} / \mathrm{P}$ ratio were higher than the recommended which is 1.0 (NRC, 1989; Ijarotimi and Keshinro, 2012). This shows that the flour blends would serve as a good source of minerals such as calcium and phosphorous, whose consumption is considered essential for bone and teeth formation in children and for regulation of calcium in the blood. Magnesium content ranged between $49.10 \mathrm{in} \mathrm{EP15}$ and $61.80 \mathrm{mg} / 100 \mathrm{~g}$ in sample EP10. Magnesium has been reported to be involved in maintaining the electrical potentials in leaves and activation of some enzymes. (Ferro et al., 1987).

Table 3. Major mineral ( $\mathrm{Na}, \mathrm{K}, \mathrm{Ca}, \mathrm{P}, \mathrm{Mg}$ and their ratios) composition (mg/100 g) of spontaneously-fermentedAfrican yam bean (AYB) (Sphenostylis stenocarpa) seed-enriched Pupuru flour blends and the commercial control

\begin{tabular}{|l|l|l|l|l|l|l|l|}
\hline Sample & $\mathrm{Na}$ & $\mathrm{K}$ & $\mathrm{Na} / \mathrm{K}$ & $\mathrm{Ca}$ & $\mathrm{P}$ & $\mathrm{Ca} / \mathrm{P}$ & $\mathrm{Mg}$ \\
\hline CP & $153.00 \pm 0.92^{\mathrm{d}}$ & $596.50 \pm 3.1^{\mathrm{c}}$ & $0.26 \pm 0.04^{\mathrm{a}}$ & $201.50 \pm 1.56^{\mathrm{a}}$ & $63.50 \pm 1.03^{\mathrm{e}}$ & $3.17 \pm 0.13^{\mathrm{a}}$ & $71.00 \pm 1.93^{\mathrm{a}}$ \\
\hline P100 & $185.00 \pm 1.06^{\mathrm{b}}$ & $596.50 \pm 3.11^{\mathrm{c}}$ & $0.33 \pm 0.08^{\mathrm{d}}$ & $135.20 \pm 1.32^{\mathrm{d}}$ & $124.00 \pm 2.14^{\mathrm{a}}$ & $1.09 \pm 0.10^{\mathrm{e}}$ & $52.50 \pm 1.34^{\mathrm{d}}$ \\
\hline EP5 & $187.00 \pm 1.87^{\mathrm{a}}$ & $604.00 \pm 3.70^{\mathrm{b}}$ & $0.31 \pm 0.07^{\mathrm{c}}$ & $196.10 \pm 1.65^{\mathrm{b}}$ & $105.30 \pm 2.33^{\mathrm{b}}$ & $1.86 \pm 0.05^{\mathrm{d}}$ & $57.38 \pm 1.05^{\mathrm{c}}$ \\
\hline EP10 & $143.00 \pm 1.19^{\mathrm{e}}$ & $537.00 \pm 2.51^{\mathrm{d}}$ & $0.27 \pm 0.03^{\mathrm{b}}$ & $129.30 \pm 1.53^{\mathrm{e}}$ & $67.90 \pm 1.14^{\mathrm{d}}$ & $1.90 \pm 0.06^{\mathrm{c}}$ & $61.80 \pm 1.13^{\mathrm{b}}$ \\
\hline EP15 & $179.00 \pm 1.06^{\mathrm{c}}$ & $675.00 \pm 3.00^{\mathrm{a}}$ & $0.27 \pm 0.05^{\mathrm{b}}$ & $177.50 \pm 1.47^{\mathrm{c}}$ & $89.60 \pm 0.05^{\mathrm{c}}$ & $1.98 \pm 0.09^{\mathrm{b}}$ & $49.10 \pm 1.04^{\mathrm{e}}$ \\
\hline
\end{tabular}

Values are means \pm SD with different superscripts in the same column are significantly different $(\mathrm{p}<0.05), \mathrm{n}=3$.

Key: CP = Commercial 100\% Cassava Pupuru Sample; P100 = 100\% Cassava Pupuru; EP5 = 5\% AYB-enriched Pupuru; EP10 = 10\% AYB-enriched Pupuru; EP15 = 15\% AYB-enriched Pupuru.

Tables 4 show the minor / trace mineral ( $\mathrm{Cu}, \mathrm{Mn}, \mathrm{Zn}, \mathrm{Fe}$ and $\mathrm{Pb}$ ) compositions of commercial, spontaneouslyfermented-African yam bean (AYB) (Sphenostylis stenocarpa) seed-enriched Pupuru flour blends. Copper in the Pupuru samples differed significantly $(\mathrm{p}<0.05)$ ranging from $2.30(\mathrm{P} 100)$ to $3.40 \mathrm{~m} / 100 \mathrm{~g}$ and were within the recommended limits (FAO/WHO, 2011; WHO and Mahler, 1975). The flour blends are therefore, suitable for consumption, without posing any form of copper toxicity. Iron contents of the flour blends studied, were higher than those recommended for men $(1.37 \mathrm{mg} /$ day $)$ and women $(2.94 \mathrm{mg} /$ day $)$. Zinc contents for the samples in this study ranged from $4.5-6.30 \mathrm{mg} / 100 \mathrm{~g}$ and were significantly $(\mathrm{p}<0.05)$ lower than in the commercial control sample. Inadequate zinc can lead to stunted growth (Guria, 2006) and the minimum daily requirement is $3 \mathrm{mg}$ (IOM, 2001). The samples could meet the minimum daily requirements. Lead was below detection level in all the 
analysed samples, indicating that the Pupuru flour blends in this study would be suitable for consumption without posing any health risks. Lead is one of the vital elements considered as an index for food-chain contamination (Emurotu et al., 2012), and the maximum recommended level is $0.2 \mathrm{mg} / \mathrm{kg}$ (FAO/WHO, 2013). This study showed that the Pupuru flour blends compared well with some cereal and legume-based complementary foods (Enomfon and Umoh, 2004; Mohamed and Huiming, 2007; Onoja et al, 2014) and also followed the trend reported for cocoyam by Njoku and Ohia, (2007).

Table 4. Minor / trace mineral ( $\mathrm{Cu}, \mathrm{Mn}, \mathrm{Zn}, \mathrm{Fe}$ and $\mathrm{Pb})$ composition $(\mathrm{mg} / 100 \mathrm{~g})$ of spontaneously-fermentedAfrican yam bean (AYB) (Sphenostylis stenocarpa) seed-enriched Pupuru flour blends and the commercial control

\begin{tabular}{|l|l|l|l|l|l|}
\hline Sample & $\mathrm{Cu}$ & $\mathrm{Mn}$ & $\mathrm{Zn}$ & $\mathrm{Fe}$ & $\mathrm{Pb}$ \\
\hline $\mathrm{CP}$ & BDL & $21.20 \pm 0.22^{\mathrm{a}}$ & $11.00 \pm 0.15^{\mathrm{a}}$ & $12.50 \pm 0.09^{\mathrm{a}}$ & $\mathrm{BDL}$ \\
\hline P100 & $2.30 \pm 1.21^{\mathrm{d}}$ & $1.70 \pm 0.24^{\mathrm{c}}$ & $6.30 \pm 0.14^{\mathrm{b}}$ & $5.20 \pm 0.10^{\mathrm{e}}$ & BDL \\
\hline EP5 & $2.50 \pm 1.01^{\mathrm{c}}$ & $1.90 \pm 0.08^{\mathrm{b}}$ & $4.50 \pm 0.10^{\mathrm{e}}$ & $5.70 \pm 0.05^{\mathrm{d}}$ & BDL \\
\hline EP10 & $2.70 \pm 1.00^{\mathrm{b}}$ & $1.20 \pm 0.14^{\mathrm{e}}$ & $5.90 \pm 0.11^{\mathrm{c}}$ & $9.00 \pm 0.07^{\mathrm{b}}$ & BDL \\
\hline EP15 & $3.40 \pm 0.19^{\mathrm{a}}$ & $1.50 \pm 0.3^{\mathrm{d}}$ & $4.80 \pm 0.17^{\mathrm{d}}$ & $7.20 \pm 0.08^{\mathrm{c}}$ & BDL \\
\hline
\end{tabular}

Values are means \pm SD with different superscripts in the same column are significantly different $(\mathrm{p}<0.05), \mathrm{n}=3$.

Key: CP = Commercial 100\% Cassava Pupuru Sample; P100 = 100\% Cassava Pupuru; EP5 = 5\% AYB-enriched Pupuru; EP10 = 10\% AYB-enriched Pupuru; EP15 = 15\% AYB-enriched Pupuru.

\subsection{Sensory Evaluation}

Table 5 shows the results of the sensory evaluation of stiff porridge dough meals prepared with the commercial and spontaneously-fermented-African yam bean (AYB) (Sphenostylis stenocarpa) seed-enriched Pupuru flour blends. Appearance ratings for all the dough meals differed significantly $(\mathrm{p}<0.05)$, ranging from 5.79 (EP15) to 7.79 (P100) and decreased with increased level of enrichment with AYB. This trend might have been due to the brown tainting of the flour blends due to Maillard reaction (a chemical reaction between amino acids and reducing sugars in the presence of heat resulting to browning of the food and formation of new aromas and flavours) during the toasting of the enriched Pupuru flour blends. This appearance trend was also reported by observed by Blanca et al. (2009) in a study that supplemented Lafun with African breadfruit 'tempe' flour, whereby, Lafun without substitution scored significantly $(\mathrm{p}<0.05)$ higher in appearance than Lafun-tempe. The significantly different $(\mathrm{p}<0.05)$ aroma of the porridge meals prepared with spontaneously fermented blends ranged from 5.96 (EP5) to 6.50 (EP15), indicating preference for the most highly enriched flour with AYB seed. The pleasant aroma of the toasted AYB seed could be attributed to the trend in these results, as supported by the finding of Njoku et al. (2013), with Lafun enriched with breadfruit tempe flour whereby Lafun-tempe scored significantly $(\mathrm{p}<0.05)$ higher in aroma than Lafun. The textural characteristic of the porridge meals prepared with all the Pupuru flour blends differed significantly $(\mathrm{p}<0.05)$ ranging from $6.42(\mathrm{P} 100)$ to $7.21(\mathrm{EP} 5)$ while CP was rated 7.00. These results were at variance with what was obtained in a study where Lafun was rated significantly $(\mathrm{p}<0.05)$ higher in texture than the Lafun-tempe (Njoku et al., 2013). This might be as a result of AYB seed being able to form a smooth bond with the cassava starch molecules more than breadfruit (tempe). 
Table 5. Sensory evaluation of stiff porridge dough meals prepared with commercial and spontaneously-fermentedAfrican yam bean (AYB) (Sphenostylis stenocarpa) seed-enriched Pupuru flour blends.

\begin{tabular}{|l|l|l|l|l|l|l|l|}
\hline Sample & Appearance & Aroma & Texture & Mouldability & Taste & Mouthfeel & $\begin{array}{l}\text { Overall } \\
\text { acceptance }\end{array}$ \\
\hline CP & $6.43 \pm 0.67^{\mathrm{o}}$ & $6.46 \pm 0.45^{\mathrm{h}}$ & $7.00 \pm 0.22^{\mathrm{e}}$ & $6.93 \pm 0.46^{\mathrm{i}}$ & $6.18 \pm 0.58^{\mathrm{l}}$ & $6.36 \pm 0.36^{\mathrm{k}}$ & $6.85 \pm 0.29^{\mathrm{f}}$ \\
\hline P100 & $7.79 \pm 0.25^{\mathrm{h}}$ & $6.43 \pm 0.21^{\mathrm{j}}$ & $6.42 \pm 0.31^{\mathrm{m}}$ & $6.36 \pm 0.85^{\mathrm{q}}$ & $6.37 \pm 0.37^{\mathrm{j}}$ & $6.22 \pm 0.56^{1}$ & $6.46 \pm 0.66^{\mathrm{m}}$ \\
\hline EP5 & $7.64 \pm 0.03^{\mathrm{j}}$ & $5.96 \pm 0.52^{\mathrm{o}}$ & $7.21 \pm 0.16^{\mathrm{c}}$ & $7.04 \pm 0.35^{\mathrm{g}}$ & $6.64 \pm 0.57^{\mathrm{b}}$ & $6.43 \pm 0.39^{\mathrm{h}}$ & $6.60 \pm 0.52^{\mathrm{j}}$ \\
\hline EP10 & $6.71 \pm 0.21^{\mathrm{n}}$ & $6.04 \pm 0.36^{1}$ & $6.79 \pm 0.39^{\mathrm{g}}$ & $7.07 \pm 0.41^{\mathrm{f}}$ & $6.21 \pm 0.36^{\mathrm{k}}$ & $6.32 \pm 0.25^{\mathrm{i}}$ & $6.66 \pm 0.21^{\mathrm{e}}$ \\
\hline EP15 & $5.79 \pm 0.17^{\mathrm{q}}$ & $6.50 \pm 035^{\mathrm{i}}$ & $6.46 \pm 0.50^{\mathrm{o}}$ & $7.25 \pm 0.43^{\mathrm{b}}$ & $6.59 \pm 0.59^{\mathrm{i}}$ & $5.85 \pm 0.45^{\mathrm{q}}$ & $6.32 \pm 0.52^{\mathrm{n}}$ \\
\hline
\end{tabular}

Values are means \pm SD with different superscripts in the same column are significantly different $(p<0.05), n=3$. Key: CP $=$ Commercial 100\% Cassava Pupuru Sample; P100 = 100\% Cassava Pupuru; EP5 = 5\% AYB-enriched Pupuru; EP10 = 10\% AYB-enriched Pupuru; EP15 = 15\% AYB-enriched Pupuru.

Mouldability of porridge meals prepared with the flour blends were significantly different $(\mathrm{p}<0.05)$ and ranged between 6.36 (P100) and 7.25 (EP15) and the commercial sample was 6.93. The taste of porridge meals prepared with the Pupuru flour blends differed significantly $(\mathrm{p}<0.05)$ ranging from 6.21 (EP10) to 6.64 (EP5) while CP was rated 6.18. The enriched samples seemed to be significantly $(\mathrm{p}<0.05)$ higher than the control samples, as in agreement with the report of Njoku et al. (2013) that Lafun-tempe scored significantly $(\mathrm{p}<0.05)$ higher in taste than Lafun. All the porridge meals prepared with Pupuru flour blends varied significantly $(\mathrm{p}<0.05)$ in mouthfeel and ranged between 5.85 (EP15) and 6.43 (EP5) with CP being 6.36. Overall acceptance of porridge meals prepared with all the Pupuru flour blends differed significantly $(\mathrm{p}<0.05)$ ranging from 6.32 (EP15) to 6.66 (EP10) while CP was rated 6.85.The results obtained for sensory evaluation of the flour blends in this study were at variance with the report of Oluwamukomi and Akinlabi (2011), in a study that enriched Pupuru with AYB seed whereby, the stiff dough meal prepared from the unenriched flour was rated significantly $(p<0.05)$ higher than the enriched samples in all the attributes (taste, aroma, colour, texture, mouldability and overall acceptance) evaluated; and the enriched samples were acceptable only up to 5\% African yam bean flour inclusion as there was no marked significant difference $(\mathrm{p}<0.05)$ between the sensory attributes of the sample and the control. The variations in the findings might be as a result of differences in the processing methods such as pre-gelatinisation at various stages, cassava and AYB seed varieties, starter cultures employed in preparing the various flour blends and flour-water ratios used to prepare the stiff porridge dough meals in both studies. There was, however, no rejection of any of the stiff porridge dough meals in this study.

\section{Conclusion}

African yam bean (AYB) (Sphenostylis stenocarpa) seed has successfully been used to enrich the nutritional, functional and sensory properties of Pupuru. The enriched Pupuru can therefore, be used to tackle protein energy malnutrition as well as mineral deficiencies in Africa.

\section{References}

Adebayo-Oyetoro, A. O., Egbedinni, M. M., Akinwande, F. F., Adeyeye, S. A. O. \& Adeoya, A. S. (2017). Quality Characteristics of Fermented Cassava Flour (Lafun) Produced Using Backslopping Method”. ECronicon Nutrition 7(2), 52-57.

Adejuyitan, J. A. (2011). Tigernut Processing: Its Food uses and Health Benefits. American Journal of Food Technology 6(3), 197-201.

AOAC. (2012). Association of Official Analytical Chemist. Official Methods of Analysis of the Analytical Chemist International, 18th ed. Gathersburg, MD USA.

Aboaba, O. O., Nwachukwu, S. U., and Opesanwo, N. A. (1988). Microorganism Associated with Cassava Fermentation for "Pupuru" Production. Journal of Food Agriculture, 2(1), 39-41.

Banjo, N. O \& Ikenebomeh, M. J. (1996). Comparison of methods for the preparation of soy "gari” from cassava and soybeans mash. Journal of Food Science and Technology, 33(4), 440-442. 
Blanca, J. V, Lianne, M. \& Lizada, M. C. (2009). Descriptive sensory evaluation of virgin coconut and refined, bleached and deodorized coconut oil. Philipines Journal of Nutrition 12, 1-4.

Buitrago, J. A. (1990). The use of cassava in animal feeding. Centro Internacional de Agricultura Tropical (CIAT), Cali (Colombia), 446

Charles, A. L., Sriroth, K. \& Huang, T. C. (2005). Proximate Composition, Mineral Contents, Hydrogen Cyanide and Phytic Acid of 5 Cassava Genotypes. Food Chemistry, 92(4), 615-620.

Chauynarong, N., Elangovan, A. V. and Iji, P. A. (2009). The potential of cassava products in diets for poultry. World's Poultry Science Journal, 65, 23-35.

Coffman, C. W. \& Grarcia, V. V. (1977). Functional properties and Amino acid Content of protein isolate from mug bean flour. Journal of Food Technology, 12, $473-484$.

Dossou, V. M., Agbenorhevi, J. K., Alemawor \& Oduro, I. (2014). Physicochemical and Functional Properties of Full Fat and Defatted Ackee (Blighia sapida) Aril Flours." American Journal of Food Science and Technology, 2(6), 187-191.

Emurotu, J. E., Salehdeen, U. M. \& Ayeni, O.M. (2012). Assessment of heavy metals level in cassava flour sold in Anyigba Market, Kogi State, Nigeria. Advances in Applied Science Research, 3(5), 2544-2548.

Enomfon, J. A. \& Umoh, I. B. (2004). Effect of Heat and Tetracycline Treatments on the Food Quality and Acridity Factors in Cocoyam (Xanthosoma sagittifolium (L) Schott). Pakistan Journal of Nutrition, 3, 240-243.

Famakin, O., Fatoyinbo, A., Ijarotimi, O. S., Badejo, A. A. and Fagbemi, T. N. (2016). Assessment of nutritional quality, glycaemic index, antidiabetic and sensory properties of plantain (Musa paradisiaca)-based functional dough meals. Journal of Food Science and Technology, 53(11), 3865-3875.

Famurewa, J. A. V., Oluwamukomi, M. O. and Alaba, J. O. (2013) Effect of Different Drying Method on the Physiochemical Characteristics of Cassava Flour (Pupuru). International Journal of Biological and Chemical Sciences, 7, 333.

Ferro, D., Barone, G., Della Gatta, G. \& Piacente, V. (1987). Vapour pressures and sublimation enthalpies of urea and some of its derivatives. The Journal of Chemical Thermodynamics, 19(9), 915-923.

Food and Agriculture Organization (FAO)/World Health Organisation (WHO). (2003). Expert report on diet, nutrition and prevention of chronic diseases. Geneva, Switzerland.

Food and Agriculture Organization (FAO) (2004). Human Energy Requirements. Food and Agriculture Organization of the United Nations, Rome.

Food and Agriculture Organization (FAO) / World Health Organization (WHO). (2011). Food Standard Programme, codex Committee on Contaminated Foods. Fifth session, The Hague, Netherlands. 21-25.

Food and Agriculture Organization (FAO) / World Health Organization (WHO). (2013). General Standard for Contaminants and Toxins in Food and Feed (Codex Stan 193-1995), adopted in 1995, revised in 2013, 59.

Guria, P. (2006). Physico-Chemical Properties, Nutritional Quality and Value Addition to Quality Protein Maize (Zea Mays L.). Master's Thesis, University of Agricultural Sciences, Dharwad.

Institute of Food Technology (IFT) (1981). Sensory evaluation guide for testing foods and beverage products. Sensory Evaluation Division. Food Technology, (35)11, 50.

Ijarotimi, O. S. \& Keshinro, O. O. (2012). Comparison between the amino acid, fatty acid, mineral and nutritional quality of raw, germinated and fermented African locust bean (Parkia biglobosa) flour. Acta Scientiarum Polonorum Technologia Alimentaria, 11(2), 151-165.

Institute of Medicine (IoM) (US) Panel on Micronutrients. (2001). Dietary Reference Intakes for Vitamin A, Vitamin K, Arsenic, Boron, Chromium, Copper, Iodine, Iron, Manganese, Molybdenum, Nickel, Silicon, Vanadium, and Zinc. Washington (DC): National Academies Press (US). ISBN-10: 0-30907279-4.

Kimaryo, V. M., Massawe, G. A., Olasupo, N. A. \& Holzapfel, W. H. (2000). The use of a starter culture in the fermentation of cassava for the production of kivunde, a traditional Tanzanian food product. International Journal of Food Microbiology, 56, 179-190.

Larmond, E. (1982). Laboratory Methods for Sensory Evaluation of Food, p. 23, Public. 1637, Communications Branch, Agricultural Canada, Ottawa KIA OC7.

Mohamed, L. B. \& Huiming, Z. (2007). Formulation and Nutritional Quality of Extruded Weaning Food Supplemented with Whole Egg Powder. American Journal of Food Technology, 2(6). DOI:10.3923/ajft.2007.477.489

Montagnac, J. A., Davies, C. R. \& Tanumihardjo, S. A. (2009). "Nutritional Value of Cassava for Use as a Staple Food and Recent Advances for Improvement," Comprehensive Reviews in Food Science and Food Safety, 8(3), 181-219.

Njoku, H. O., Ibe, S. N., Odu, N. N. \& Oyeyipo, O O. (2013). Processing and characteristics of African breadfruit tempe-fortified lafun. Nature and Science, 11, 116-120. 
Njoku, P. C. \& Ohia, C. C. (2007). Spectrophometric Estimation Studies of Mineral Nutrient in Three Cocoyam Cultivars. Pakistan Journal of Nutrition 6, 616-619.

National Research Council (NRC) (1989). Recommended Dietary Allowances: 10th Edition. Washington (DC): National Academies Press, United State.

Nwabueze, T. U. \& Odunsi, F. O. (2007). Optimization of process conditions for cassava (Manihot esculenta) lafun production. African Journal of Biotechnology, 6(5), 603-611.

Ogunjobi, M. A. K. \& Ogunwolu, S. O. (2010). Physicochemical and Sensory Properties of Cassava Flour Biscuits Suplemented with Cashew Apple Powder. Journal of Food Technology 8, 24-29.

Okafor, N., Umeh, C. \& Ibenegbu, C. (1998). Amelioration of garri, a cassava-based fermented food by the inoculation of microorganisms secreting amylase, lysine and linamarase into cassava mash. World Journal of Microbiology and Biotechnology, 14, 835-838.

Olugbemi, T. S., Mutayoba, S. K. \& Lekule, F. P. E (2010). Effect of Moringa (Moringa oleifera) inclusion in cassava based diets fed to broiler chickens. International Journal of Poultry Science 9(4), 363-367.

Oluwamukomi, M. O. and Akinlabi, A. A. (2011). Nutritional Enrichment of "Pupuru" and smoked-dried Cassava product with African yam bean Seed flour. Annals of Science and Biotechnology, 2(1), 26-35.

Onoja, U. S., Akubor, P. I., Gernar, D. I. \& Chinmma, C. E. (2014). Evaluation of Complementary Food Formulated from Local Staples and Fortified with Calcium, Iron and Zinc. Journal of Nutrition and Food Science, 4, 326.

Opeke, L. K., Laogun, E. A., Onayemi, O. O., Adetiloye, P. O. \& Williams, T. O. (1986). The Place of Cassava in Household Food Security and Nutrition. A Rapid Case Study of Owo Local Government Area, Ondo State, Nigeria. A Report on the existing Storage and Processing Technology in the Southern Nigeria. UNICEF/IITA. 75-87.

Pearson, D. A. (1976). Chemical Analysis of Foods. 7th Edition. Church Hill Livingstone, New York, 1, $422-511$.

Shittu, T. A., Oyewole, O. B., Olawuyi, O. \& Daramola, O. (2003). Processing Technology of Pupuru: A Survey of Practices and Product Quality in the South West of Nigeria. ASSET Series B, Natural Sciences, Engineering and Technology, 2(2), 17-27.

Steel, R., Torrie, J. \& Dickey, D. (1997). Principles and Procedures of Statistics: A Biometrical Approach, 3rd ed., McGraw Hill Book Co., New York, USA

Takashi, S. \& Sieb, P.A. (1988). Paste and gel properties of prime corn and wheat starches with and without native lipids. Cereal Chemistry, 65, 474-483.

World Health Organization (WHO) and Mahler, H. (1975). The work of WHO, 1974: annual report of the DirectorGeneral to the World Health Assembly and to the United Nations. Official records of the World Health Organization, No. 221.

Wobeto, C., Corrêa, A. D., Patto de Abreu, C. M., Donizete dos Santos, C. \& Pereira, H. V. (2007). Antinutrients in the cassava (Manihot esculenta Crantz) leaf powder at three ages of the plant. Food Science and Technology, 27(1). http://dx.doi.org/10.1590/S0101-20612007000100019. 